\title{
Arabic Calligraphy in the Art of Glass Painting From Cirebon by Raffan S. Hasyim
}

\author{
Furqon Nurhidayat*, Juju Masunah, Tri Karyono \\ Universitas Pendidikan Indonesia \\ Bandung, Indonesia \\ *nh.furqon@gmail.com
}

\begin{abstract}
Arabic calligraphy is one of the themes in Cirebon glass painting. Called Arabic calligraphy glass painting because this painting uses transparent glass media that is painted in reverse with images in the form of writings or Arabic letters created into figures or figures of wayang, serabad, and others. The beginning of the emergence of Arabic calligraphy in Cirebon glass paintings was the influence of Islamic culture spreaded by the saints as a means of spreading Islam in Cirebon. The writing of this article aims to discuss the visual art of Arabic calligraphy in Cirebon glass painting by Raffan S. Hasyim, especially in the design and manufacturing process. The research method uses descriptive analysis. Data obtained from the results of the library, techniques and creative process of making glass calligraphy paintings by Raffan S. Hasyim through literature studies, and observations. The results showed that Cirebon glass painting by Raffan S. Hasyim had followed the proportions and structure formulated in the traditional aesthetics of glass painting, but he also added his own unique image characterized by shading details, color gradations and elements in his calligraphy glass painting decoration. the typical, and the manufacturing process using a ruler and complex mathematical calculations.
\end{abstract} letters

Keywords-Arabic calligraphy, glass painting, painting, Arabic

\section{INTRODUCTION}

The influence of Islam spreaded by the saints also became a feature of Cirebon glass paintings. According to Putra, there are 42 types of calligraphy left by saints, especially Sunan Gunung Jati [1]. The fame of this art lies in the freshness of the colors produced and the durability of the glass [2].

Glass painting is a cultural property owned by Cirebon artists such as Raffan S. Hasyim or commonly called Opan. Opan is one of the glass painting artists as well as cultural figures in Cirebon, dealing with historical values and making glass paintings he mastered. His life as a pesantren graduate has made him to have a strong Islamic foundation related to the creation of painting, especially Arabic calligraphy glass painting. According to Arya Sadewa, in Islamic civilization, Arabic writing culture plays an important role, in this case calligraphy becomes the highest art and a symbol of Islamic art [3]. Opan Arabic calligraphy glass paintings become more interesting when they know the manufacturing process is also the basis of science and experience that he uses. His syattariyah tarekat study on pictorial calligraphy and the deepening of illustrated images and calligraphic illuminations are the reason why his works can have high philosophical and aesthetic values.

When expressing the aesthetic value of calligraphy glass painting, of course, we must know the technique of making it so that the delivery of his work is as perfect as that of Opan. According to Kalam, states that to be able to express the aesthetic sense of art, an artist must create technical masters [4]. A creator who is not technically proficient will not be perfect in his delivery. Similarly, painting must be realized in the form of lines and colors. The purpose of writing this article is to analyze the work of Arabic calligraphy on a glass painting by Opan. In the works in the world of Opan calligraphy glass painting, there is no doubt that the traditional methods that are still maintained are also an interesting part of Opan's work, by prioritizing the process of working manually but giving maximum results.

\section{RESEARCH METHODS}

Research conducted in writing this article is to use descriptive analytic methods with a qualitative approach. The use of this approach is adapted to the background of the study, which is describing and analyzing Arabic calligraphy in glass painting by Raffan S. Hasyim.

In this process every step taken to explore information regarding Arabic calligraphy in glass painting by Raffan S. Hasyim will be examined, so it is hoped that the data obtained will be more complete, deeper, reliable and more meaningful.

Regarding qualitative research, Bogdan and Biklen, suggested, there are five characteristics as follows [5]:

From the opinion above it was stated that the characteristics of qualitative research are: (1) Qualitative is a natural setting as a source of direct data and researchers become the main instrument, (2) Qualitative research is descriptive. Data collected in the form of words and images, not numbers, (3) Qualitative research regarding the process rather than solely the results or products, (4) Qualitative research prioritizes general 
data processing first, (5) The meaning is the main concern in qualitative research.

Qualitative research procedures do not have a standard pattern. Qualitative research collects and records detailed data from various problems related to the object of research. The data collection was directly carried out by the researchers themselves by conducting observations and direct interviews with Raffan S. Hasyim.

\section{RESULTS AND DISCUSSION}

\section{A. Development of Cirebon Calligraphy Glass Painting}

In the early days of Cirebon glass painting, puppet themes were combined with Islamic calligraphy. These art work missions are more suggestions of social ethics based on Kejawen's moral teachings through puppet symbols, added and integrated with Islamic teachings through Al-Qur'an verses. This creative process is religion and belief [6].

Cirebon glass painting works mostly take two motif themes, namely puppet themes and Sufism (Islamic) calligraphy. According to Budiono, this calligraphy theme can be categorized into two broad categories [7]: 1) Calligraphy which only emphasizes Arabic writing accompanied by local ornaments such as wadasan motifs, vine motifs or leaves. 2) Calligraphy with Arabic script by borrowing puppet figures as a form of calligraphy.

According to Sirajuddin, "Khat or calligraphy is a science that introduces the forms of single letters, their locations, and ways to compile them into a compiled writing" [8]. As according to Oloan Situmorang, according to the provisions that have been standardized (following a pattern that has been agreed upon) in the art of pure Arabic calligraphy (Arabic Khath), it can be known several types of Arabic calligraphic khat flow namely: Khat Koufi, Khat Naskhi, Khat Tsuluts "Khat Farisi, Khat Riq 'ah, Khat Diwani and Khat Rayhani" [9].

Khat Naskhi is the khat most often used by Opan in creating Arabic calligraphy glass paintings (see figure 1). One of them is on a century theme.

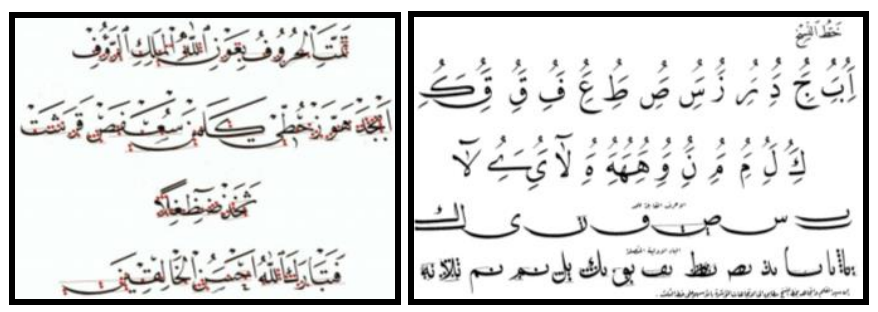

Fig. 1. Khat Naskhi.

One of the inspirational decoration of Opan's calligraphy glass paintings is from illustrations and illuminations in the syattariyah tarekat text. There are a lot of Syattariyah (NTS) tarekat texts in Cirebon. The Syattariyah Tariq Manuscript has beautiful writings and illuminations. The function of illumination is to serve anything that is not presented by the text. Illumination also has a function to make a tamsilan (analogy) lesson in monotheism. Besides functioning as a lesson, illumination also has a high aesthetic value. that is one of the reasons why Opan illuminates this tarekat into glass paintings.

\section{B. About Raffan S. Hasyim}

Raffan S. Hasyim was born in Pilangsari Village, Kedaung District, Cirebon, May 9, 1967, and has the full name R. Achmad Opan Safari Hasyim, with the nickname Opan, Opan is the 3rd child of 5 siblings. Opan was married to Eroh Maesaroh and blessed with two daughters of Mutiara Zulfiyah Rafania and Emilia Muftuhatul Fikroh.

Opan took basic education at SD Negeri 1 Kedaung Cirebon (graduated in 1981), SMP Negeri 3 Cirebon (1984), SMA Negeri 4 Cirebon (1987). Bachelor degree program at IAIN Sunan Gunung Jati Cirebon, English Department graduated (1994). The ability to speak English can make it easier for Opan to develop works of art through deepening of knowledge both directly from national and international artists, as well as through art books that are mostly in English. Graduates of the Philology master program at Unpad (2009), and the Unpad Philology doctoral program graduated (2016).

Besides being a civil servant in MTs Karangkendal Negeri Cirebon, also as a lecturer at IAIN Sheikh Nurjati and ISIF Cirebon. Opan owns a glass painting studio, Sanggar Noerdjati in Kedawung. In addition, throughout 30 years of painting glass, he is also still actively training children to paint glass in Mayung Village, Cirebon Regency.

Opan began drawing with glass media in 1988. Opan's first calligraphy glass painting was a painting of Arabic calligraphy, tiger, ali and a century. Some of the Arabic calligraphy glass paintings that have been made to date by Opan include paintings of ali tiger, insan kamil paintings, semar paintings, bald mountain paintings. In addition to traditional glass paintings, Opan also makes modern glass paintings such as calligraphy glass paintings of Al-insyirah, Al-Fatihah, Albaqarah, Al-sincere, chair verses and others with geometric shapes and other decorative ornaments. Opan's calligraphy glass painting can be seen in figure 2 .

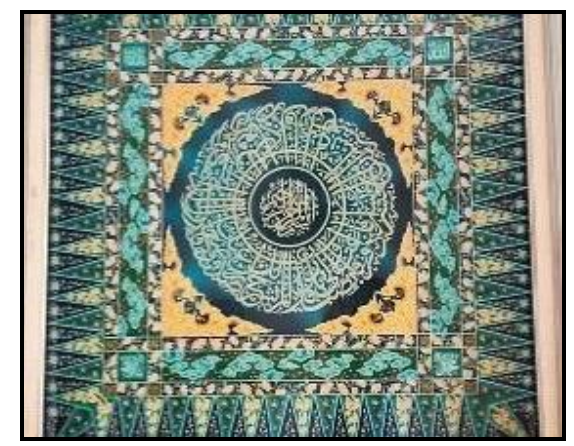

Fig. 2. Raffan S. Hasyi's (calligraphy khat) work on Cirebon calligraphy glass paintings. 
Opan's initial interest in exploring and making works of Arabic calligraphy glass began when Opan completed his master's degree with the thesis research of the syattariyah katrabonan tarekat which is a philological study. When studying the Syattariyah order many images such as illustrations and illuminations in the form of calligraphy (calligraphy calligraphy) such as calligraphy Salira Muhammad which is Muhammad's lafadz and Allah's lafadz combined into human figures, some in the form of fish, lotus, elephant calligraphy such as calligraphy Salira Muhammad which is Muhammad's lafadz and Allah's lafadz combined into human figures, some in the form of fish, lotus, elephants those are all starting with Arabic calligraphy writing. With the study of drawings, this is one of the things that makes Opan even the only thing that made Opan even more interested and inspired him to create many Arabic calligraphy glass paintings.

One of the reasons his works in painting Arabic calligraphy is not just ordinary works, but works that have a strong scientific basis and meaning in terms of Islamic depth is because Opan had been in a boarding school environment for 14 years.

While exhibitions of his work have been carried out in Jakarta, Denpasar, Bandung, Surabaya and Adelaide in South Australia. What is interesting is that he exhibited without using government funds, and also during his time as a glass painter, he never relied on government assistance. Some of his works are stored in the Purwakarta Museum, the official residence of the Governor of West Java, the Children's Palace of Taman Mini Indonesia Indah (TMII), and several overseas collectors, and so on.

\section{Cirebon Calligraphy Glass Painting Materials Raffan S. Hasyim}

1) Tool: The tools used in the process of making Cirebon calligraphy glass paintings are still relatively simple and still traditional, including:

a) Pen (for making contours): This pen is a mandatory equipment commonly used as a tool for making contours and making details on drawings or Arabic calligraphy patterns in Cirebon glass paintings, usually the tip of this pen is sharpened routinely to be able to make neat line patterns. The pen used is made by Opan can be seen in figure 3 .

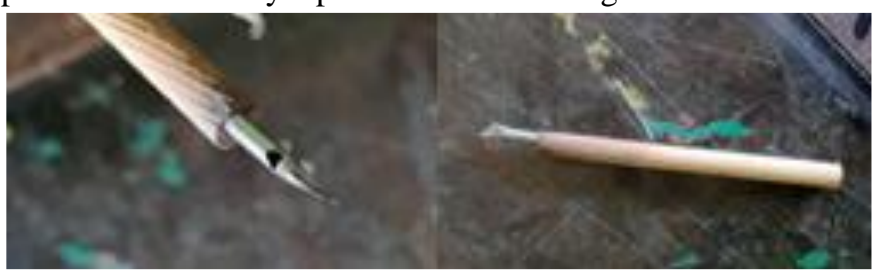

Fig. 3. Glass painting pen

b) Tracing paper: This transparent paper is usually used to make the initial design of calligraphy sketches in Cirebon glass painting. c) Pencil: This pencil is used as a drawing aid for sketching on tracing paper.

d) Baygon spray: This used spray which is usually used up after being discharged, is actually used as a place to store paint and also as a tool such as spray to give texture to the background of Cirebon calligraphy glass painting (see figure 4)

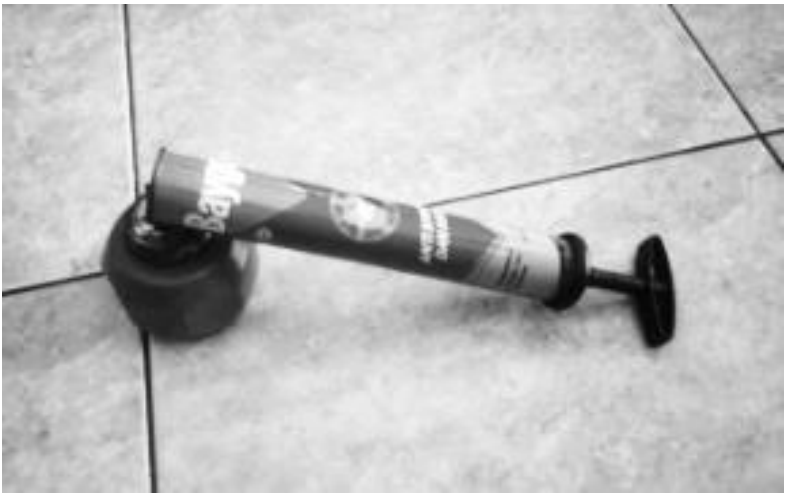

Fig. 4. Baygon mosquito spray as an alternative compressor.

e) Brush: This tool is the equipment commonly used for the coloring stage of the core parts of Cirebon calligraphy glass painting.

f) Ruler: Ruler is very necessary in making calligraphy glass paintings as a benchmark so that it can be precise.

g) Term: This term is a tool that is routinely used to assist in the process of making Arabic calligraphy patterns on glass paintings manually.

h) Supporting tools: Supporting tools used by Opan include: Cutter knife, Lap for finishing process so that the results are neater and cleaner, Table as a place to support painted glass.

\section{2) Material}

a) Transparent glass: The basic ingredients of calligraphy glass painting use transparent glass whose size is adjusted to the needs (see figure 5).

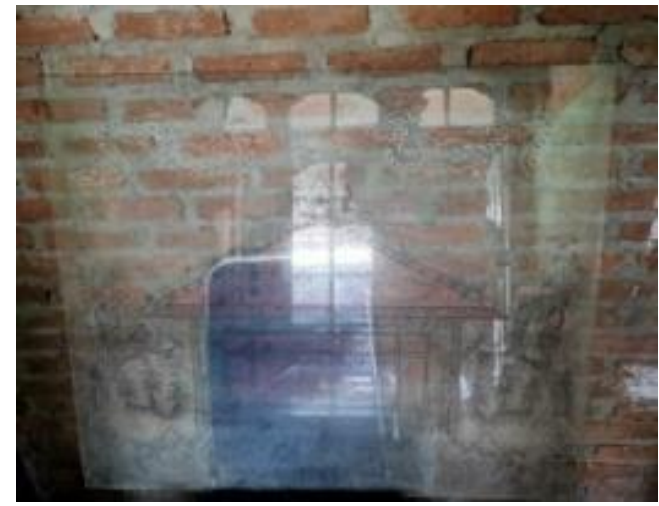

Fig. 5. Transparent glass as a medium in glass painting. 
b) Prada powder: This material is used to give a golden color to the background of the calligraphy glass painting (see figure 6).

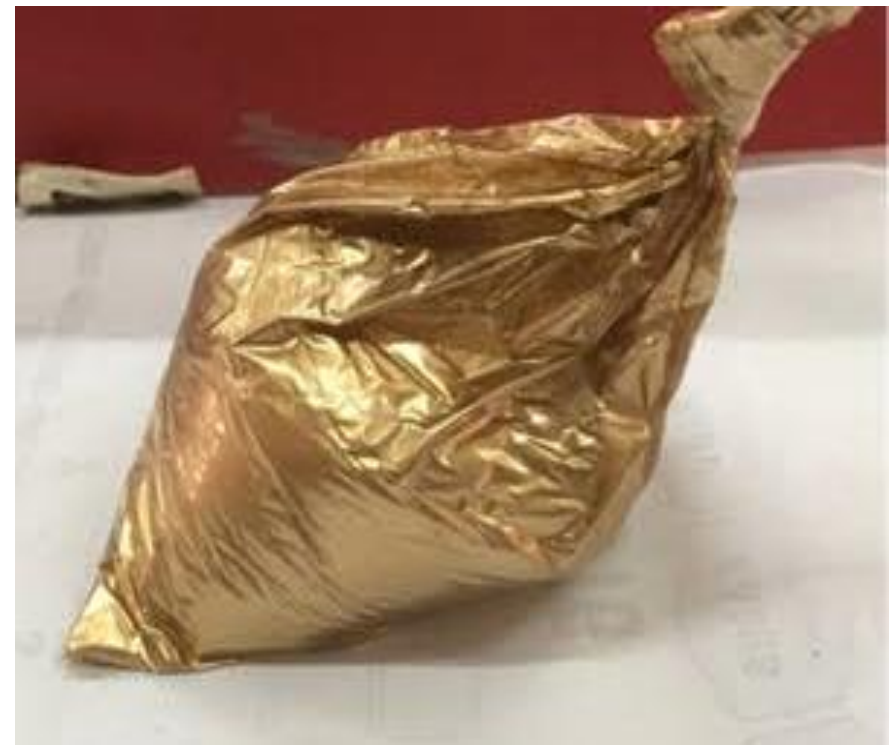

Fig. 6. Prada powder.

3) Paint (coloring): Since the beginning of painting calligraphy glass until now, in the case of giving Opan colors always use glass paint or wood paint Kuda Terbang brand (see figure 7). while as an additional variation in making Opan calligraphy glass painting decoration using gold or silver bromine paint.

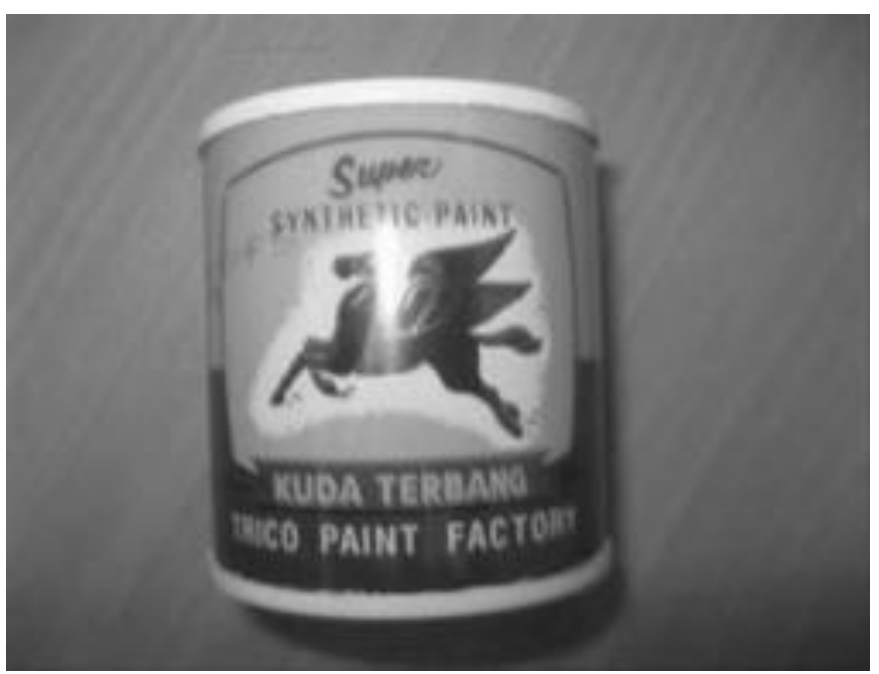

Fig. 7. Glass paint marked Kuda Terbang.

\section{Cirebon Calligraphy Glass Painting Technique of Raffan S. Hasyim's}

In the work of his works, Opan only uses manual equipment (not using pilox, compressors and other modern equipment) or traditionally.

The advantages of Opan in the art of glass painting, using the bar and mathematical calculations that are complex and detailed. Such as the division of space from small painting objects, making detail shading, gradations of color and traditional elements. Everything is done manually to produce interesting effects in his work.

Line making or outlines only use the bar, pencil and run manually. The existence of the manual manufacturing process actually presents its own challenges for Opan to be able to produce beautiful works.

When making a line as a start in drawing glass paintings, Opan makes a division of its shapes to make it easier to produce and produce precise and neat shapes of calligraphy or drawings.

Making textures or patterns on calligraphy glass paintings, Opan uses gradation elements (young and old, young and old) so that images of objects stand out, form depth, (far-near) in perspective, and also impression (dark-light).

\section{E. The Creation Process of Cirebon Calligraphy Glass Painting Raffan S. Hasyim}

The creative process is appreciated through intensive internal and external dialogue. internal dialogue places the incubation processes of aesthetic experience, imagination, intuition, talent, sensing the painter as the driving force for the emergence of sense consciousness. Aesthetic quality is largely determined by the quality of working techniques and the tools and materials used. The technique in painting Arabic Opan calligraphy glass designs itself from several terms, including:

- Ngerengreng, making contours on glass or making outlines using silver color;

- Ngisen, making detailed drawings of calligraphy glass painting using custom sharpened pens;

- Nyungging, giving color to calligraphy glass paintings;

- Natar, making background on calligraphy glass painting using mosquito spray.

In the cultivation of his works Opan uses an outline (contour) using silver which is usually elsewhere using black. The use of this silver outline technique is much more difficult because when it isn't dry this color will look transparent. However, with the use of this silver outline technique a neater work is produced which makes it characteristic of Opan's works. The terms in glass painting are taken from a number of artistic terms such as the terms of making batik and shadow 
puppet coloring which are then assembled by Opan into stages in the technique of glass painting.

\section{CONCLUSION}

Raffan S. Hasyim (Opan) is one of the important figures in the world of calligraphy glass painting in Cirebon who has remained productive as a painter until now.

He created traditional paintings that were purely his own version. His work fulfills portions and structures formulated in traditional aesthetics, but he also adds his own distinctive touch to that style. The strengths of his work are characterized by gradations of color and illumination on the distinctive edge decoration of his calligraphy glass painting, a combination of batik motifs, shadow puppets, wood carvings and the process of making detailed outlines of Arabic calligraphy that are neatly colored in silver, using a ruler and complicated mathematical calculations.

\section{ACKNOWLEDGMENT}

The researchers wish to express gratitude and appreciation to the committee of ICADE FPSD Universitas Pendidikan Indonesia (UPI) for the support and Atlantis Press Publisher for the opportunity in publishing this research.

\section{REFERENCES}

[1] R.A.A. Putra, Perancangan Media Informasi Seni Lukis Kaca Khas Cirebon. Bandung: JBPTUNIKOMPP, 2011.

[2] H. Cholis, "Seni Lukis Kaca Cirebon Refleksi Akulturasi Budaya," Brikolase: Jurnal Kajian Teori, Praktik dan Wacana Seni Budaya Rupa, vol. 1, no. 2, 2009.

[3] D.A. Sadewa, M.A. Syafei, and M.P. Efrizal, "Kajian Jenis Khat, Media Dan Warna Kaligrafi Arab Di Masjid Keramat Desa Pulau Tengah Kabupaten Kerinci Provinsi Jambi," Serupa The Journal of Art Education, vol. 6, no. 2, 2018.

[4] A.A.R. Kalam,. Transformasi Penciptaan Seni Lukis Bali Sebuah Pengkajian Seni Murni. Denpasar: Laporan Penelitian Institus Seni Indonesia Denpasar, 2007.

[5] R. Bogdan and S.K. Biklen, Qualitative research for education. Boston, MA: Allyn \& Bacon, 1997.

[6] E.H. Waluyo, Lukisan Kaca Cirebon dari Masa Awal Hingga Kini. Bandung: P4ST UPI., 2006.

[7] K. Budiono, "Makna lukisan kaca Cirebon," Makna Lukisan Kaca Cirebon, vol. 2, no. 5, pp. 1-12, 2002.

[8] A.R.D. Sirajuddin, Seni kaligrafi Islam. Jakarta: Pustaka Panjimas, 1985.

[9] O. Situmorang, Seni rupa Islam: Pertumbuhan dan perkembanganyan. Bandung: Angkasa, 1993. 